Katsaus

\title{
Paikannimien kerrostumat maaseudulla ja kaupungissa nimistöntutkijan kohteina
}

\author{
Terhi Ainiala
}

hminen on nimennyt ympäristössään kaikki ne kohteet, jotka ovat hänelle tärkeitä. Näillä I kohteilla, mäennyppylästä ja kadusta kaupunkiin ja maakuntaan, on nimi. Paikannimet kertovat, mitkä paikat ihmiselle ovat - ja ovat olleet - keskeisiä. Merkityksetöntä kohdetta ei nimetä, ja toisaalta nimistö muuttuu koko ajan. Se, mikä vielä muutama vuosikymmen sitten oli alueen asukkaille olennaista, ei ehkä ole sitä enää nyt. Silti keskeisimmät paikat säilyttävät nimensä tai ainakin pysyvät nimettyinä vuosisatoja tai jopa -tuhansia. Yleisimmin paikat ovat tärkeitä liikkumisen, paikassa orientoitumisen, asumisen, työskentelyn ja muun toiminnan vuoksi.

Erisnimet eli proprit ovat universaaleja eli kaikissa tunnetuissa kielissä ja kulttuureissa on henkilön- ja paikannimiä (esim. Bright 2003, 671-673; Kiviniemi 1990, 11). Tarve yksilöidä henkilöitä, paikkoja ja muitakin kohteita sekä kielellisesti erottaa ne toisistaan on siis eri kulttuureille ja yhteisöille yhteinen.

Esittelen tässä katsauksessa paikannimien tutkimusta. Paneudun paikannimien syntyyn ja kehitykseen sekä maaseudulla että kaupungeissa. Perinteentutkimus ja paikannimien tutkimus kytkeytyvät monin tavoin yhteen, koska paikannimien avulla voi saada monipuolista tietoa siitä, mitkä paikat ovat olleet ihmisille tärkeitä, millä tavoin ja myös mistä syistä. Paikannimet kantavat tietoa paikan ja ihmisen suhteesta, ja paikannimien tulkinta on onnistuneinta, kun se tehdään ymmärtäen paikannimien luonne ja erityispiirteet.

\section{Avaimia ja aineistoja paikannimistön tutkimukseen}

Paikannimet voidaan karkeasti jakaa kahteen pääluokkaan: perinnäisiin ja suunniteltuihin nimiin. Perinnäiset paikannimet ovat spontaanisti kansan suussa syntyneitä nimiä, joita on valtaosa suomalaisesta nimistöstä. Kaikki vanhimpiin paikannimikerrostumiin kuuluvat paikannimet ovat tällaisia. Suunnitellut paikannimet puolestaan ovat tyypillisiä rakennetulle ja kaavoitetulle ympäristölle. Niiden pohjalta on taas voinut syntyä epävirallisia variantteja (ks. Ainiala ym. 2008, 88-89).

Kaikista Suomen paikannimistä valtaosa on perinnäisiä nimiä. Siihen, kuinka paljon paikannimiä Suomessa yhteensä on ja on ollut, on mahdoton antaa vastausta. Paikannimistö on 
jatkuvasti muuttuva ja kerroksellinen kokonaisuus, eikä mihinkään kokoelmiin tai rekistereihin saada koskaan tallennetuksi kaikkea mahdollista nimistöä. Hieman osviittaa paikannimien määrästä antaa kuitenkin se, että Maanmittauslaitoksen paikannimirekisterissä on noin 800000 karttanimeä ja Kotimaisten kielten keskuksen Nimiarkistossa puolestaan jopa 2,6 miljoonaa paikannimeä (ks. Ainiala ym. 2008, 43, 49). Edellinen sisältää (karkeasti sanottuna) laajemmin käytössä olevaa ja karttoihin vakiinnutettua nimistöä, kun jälkimmäisessä on edellisten lisäksi myös pienten paikkojen käytössä olevaa ja ollutta suppealevikkistä nimistöä. Tosin paikannimirekisterissä on jonkin verran nimiä, etenkin taajamaympäristöjen nimiä, joita Nimiarkistosta puuttuu. Nimiarkiston kokoelmat eivät ylipäänsä sisällä kaikkea mahdollista nimistöä, vaikka ne kansainvälisestikin ovat kattavat.

On arvioitu, että maaseudun perinnäisten paikannimien määrä olisi ollut suurimmillaan 1900-luvun alkuvuosikymmeninä, jolloin nimiä olisi ollut maassamme ainakin kolmisen miljoonaa (Kiviniemi 1990, 33-34). Oma käsitykseni on, että nimien määrä on voinut olla tätä huomattavastikin suurempi, kun huomioon otetaan se, että erilaisilla käyttäjäryhmillä - kuten naisilla, lapsilla ja nuorilla, muualta muuttaneilla - on ollut käytössään myös omaa nimistöä. Nimiarkiston kokoelmista pääosa on kerätty 1960-70-luvuilla, jolloin talteen on keruutavoitteen mukaisestikin saatu nimistöä, joka ei keruuaikana enää ollut käytössä. Koska aikakauden keruutavoitteet ohjasivat tallentamaan maaseudun kylissä paikallaan pysyneiden, paikallismurretta taitavien ennen kaikkea vanhemman polven miesten käyttämää nimistöä, on keräämättä jäänyt monien muiden käyttäjäryhmien nimistöä. ${ }^{1}$ Nimiarkiston kokoelmien voi näistä syistä sanoa edustavan vain osittain ja valikoidusti 1900-luvun agraariväestön nimistöä. Kaupunkimaisten ja taajamaympäristöjen nimiä ei juuri edes tallennettu. Osa kokoelmista on peräisin 1900-luvun alkupuoliskolta, ja 1990-luvun jälkeen kokoelmia on täydennetty vain satunnaisesti.

Koska ympäristöt poikkeavat toisistaan monin eri tavoin eri puolilla maata eivätkä yhteisöt ole nimenkäyttötarpeiltaan samanlaisia, ei nimien määräkään (esimerkiksi edellä mainittu noin kolme miljoonaa nimeä) jakaudu maassa tasaisesti. Erilaisissa maisemissa ja erilaisilla yhteisöillä on tarve nimetä eri kohteita. Maanviljelysyhteisössä tarvitaan nimiä erilaisille paikoille kuin vaikkapa eränkävijä- tai kalastusyhteisössä (ks. esim. Pitkänen 1996). Nimiarkiston kokoelmien perusteella on tehty laskelmia siitä, mikä on nimitiheys eli paikannimien lukumäärä yhden pinta-alayksikön alueella. Keskimääräinen nimitiheys on noin seitsemän paikannimeä neliökilometriä kohden. Vaihtelu alueiden kesken on kuitenkin suurta. Suurimmillaan nimien määrä on tehdyissä laskelmissa ollut yli 30 nimeä. Nimitiheys riippuu luonnollisesti paikannimikeruun tarkkuudesta, mutta olennaisesti siihen vaikuttavat myös asutustiheys ja asutuksen ikäkin. Mitä pitempään alueella on asuttu, sitä useampia nimikerrostumia on ehtinyt muodostua. Lisäksi tiheä asutus lisää tarkkapiirteisemmän yksilöinnin tarvetta. Myös luonnonolot vaikuttavat nimitiheyteen. Vaihtelevassa maastossa nimettäviä kohteita on enemmän tarjolla kuin yksitoikkoisessa maisemassa. (Kiviniemi 1990, 35-36.)

Käytän tässä katsauksessa nimimaiseman käsitettä tarkoittamaan tietyn alueen paikannimistöä kokonaisuudessaan. Tähän nimimaisemaan kuuluu tavallisesti sekä perinnäisiä että suunniteltuja paikannimiä. Voidaan puhua myös yksittäisen henkilön tai ryhmän nimimaisemasta, jolloin tarkoitetaan tämän tuntemaa nimistöä tietyllä alueella. Seuraavissa luvuissa tarkastelen perinnäisiä ja suunniteltuja paikannimiä eri kerrostumineen.

$1 \quad$ Paikannimien keruun tavoitteista ja tuloksista ks. Ainiala 2001. 


\section{0}

\section{Perinnäiset paikannimet}

Perinnäiset paikannimet ovat tavallisia maaseudulla, mutta ne muodostavat myös kaupunkija taajamaympäristöjen nimistöjen ytimen. Agraarissa ympäristössä on nimetty kaikki yhteisölle tärkeät asumukset, alueet, viljelykset ja erilaiset rakennetut kohteet (kuten tiet, sillat, ladot ja myllyt) sekä luonnonpaikat. Nykyisessä urbaanissa maisemassa esimerkiksi kaupunginosien nimet ovat usein entisiä kylien nimiä. Oman kotikaupunginosani Helsingin Pakilan nimen taustalla on kylännimi Baggböle, joka puolestaan pohjautuu talonnimeen, joka taas sisältää henkilön lisänimen Bagge. Vanhimmat asiakirjamerkinnät kylännimestä ovat 1500-luvulta ja henkilönnimestä 1400-luvulta. Suomenkielinen nimi Pakila on 1900-luvulla käyttöön tullut mukaelma alkuperäisen ruotsinkielisen nimen pohjalta. (Helsingin kadunnimet 1981, 170; Kepsu 2005, 65.) Myös kadunnimiin voi sisältyä vanhoja kulttuuri- ja luonnonkohteiden nimiä. Esimerkiksi Helsingin Vuosaaressa Hevossaarentie, liluodontie, Leppäniementie, Porslahdentie ja Uutelantie sisältävät perinnäisiä vesistökohteiden ja tilan nimiä (Vuolteenaho ym. 2007, 17-18). Suunniteltu kaavanimistökin sisältää siis lukuisia perinnäisiä paikannimiä.

Sekä maaseudulla että urbaanissa ympäristössä nimistö on monin tavoin kerroksellista, jo pelkkä perinnäinenkin paikannimistö. Ajallisesti vanhimmat kerrostumat muodostuvat nimistä, jotka on saatettu antaa ennen kuin alueet ovat tulleet pysyvästi asutetuiksi. Nimet voivat siis olla seudulla vuosituhansiakin sitten liikkuneiden eränkävijöiden antamia. (Ks. tarkemmin esim. Ainiala ym. 2008, 114-123.) Maaseudun maiseman kaikki nimet eivät siis välttämättä ole paikallaan pysyneen agraariväestön antamia, kuten eivät - edellisen kappaleen esimerkkien lailla - kaupunkimaiseman nimet ole kaupunkilaisten antamia. Ajallisten kerrostumien lisäksi nimistössä on eri käyttäjäryhmien antamia ja tuntemia nimiä. Jos nimenantajayhteisöt ovat puhuneet eri kieliä, tämä näkyy nykynimistössä eri kielellistä alkuperää olevina niminä. Tunnettuja esimerkkejä ovat saamelaisväestön antamat nimet, joista eteläisimpiä lienee Espoon Nuuksio (Ainiala ym. 2008, 129-130; SPNK 2007). Pääkaupunkiseudulla ja maamme muilla rannikkoalueilla vanhempi suomen- ja nuorempi ruotsinkielinen nimistö kuuluvat samaan maisemaan. Monen suomenkielisen nimen taustalla on alkuaan ruotsinkielinen nimi, kuten edellä esitetyssä Pakila-nimessä, ja päinvastoin.

Perinnäiset paikannimet ovat syntyneet "itsestään", spontaanisti yhteisön parissa. Kun on tullut tarve nimetä jokin paikka, esimerkiksi kallio tai järven lahti, on alueen yhteisö antanut paikalle nimen. Nimen antaminen ei liene ollut mikään erityinen tapahtuma tai teko, vaan nimi on voinut muodostua paikalle hieman huomaamattakin. Kalliota, jonka liepeillä on usein nähty ilveksiä, on alettu kutsua Ilveskallioksi. Kun samasta paikasta on ollut tarvetta puhua useamminkin, on nimi vähitellen vakiintunut ja kenties levinnyt laajempaan käyttöön. (Paikannimien synnystä ks. esim. Bright 2003, 673-678; Kiviniemi 1975, 11-13.)

Nimenantajayhteisöt ovat yleensä olleet pieniä, ja nimet, jotka nykyisin ovat laajalti tunnettuja, eivät sitä alun perin ole olleet (Ainiala ym. 2008, 88). Päijänteenkin on luultavimmin nimennyt jokin pieni eränkävijäyhteisö. Nimeäminen on siis enimmälti pohjautunut "sammakkoperspektiivin" kokemuksiin. Paikka on voinut saada nimensä sen mukaan, missä se sijaitsee (Haukijärvenoja, Etelämäki), millainen se on ominaisuuksiltaan (Pitkämäki, Korkeasaari, Mustalampi), mitä siellä on tai kasvaa (Myllymäki, Ilveskallio, Mäntykangas) tai mitä siellä on tapahtunut, mitä siellä tehdään tai kenen paikka on (Surmaluoto, Tanssikallio, Mattila). Edellä mainitut neljä ryhmää ovat paikannimien nimeämisperusteita. Ne on saatu 
selville laajoihin paikannimiaineistoihin, Nimiarkiston kokoelmiin pohjautuvan tutkimuksen perusteella, ja taustalla on siis täsmällinen tieto siitä, millaisia suomalaiset paikannimet ovat. Systemaattisen analyysin jälkeen nimet on voitu luokitella näihin neljään päänimeämisperusteryhmään. Jos tutkijalla on riittävä tieto nimen taustasta, hän yleensä pystyy analysoimaan nimen luotettavasti ja sijoittamaan sen johonkin näistä neljästä ryhmästä. (Ainiala ym. 2008, 101-110; Kiviniemi 1987.)

Paikannimi on lähes aina syntynyt ympäristössä, jossa on jo entuudestaan nimettyjä paikkoja. Olemassa olevien nimien antama malli on monin tavoin voinut vaikuttaa myöhempiin nimiin. Nimistöntutkijan on syytä ottaa huomioon se nimistökokonaisuus eli nimisysteemi, jonka osa nimi on. Alueellinen nimistö muodostaa nimenkäyttäjien kannalta toimivan kokonaisuuden ja tarkoituksenmukaisen systeemin. Yksittäistä nimeä on hyvin hankala tulkita luotettavasti, jos ei ole tietoa siitä, minkä kokonaisuuden osa nimi on. (Ainiala ym. 2008, 96.)

Suomalaisessa nimistössä kaikkein tavallisin nimeämisperuste on sijainti ja vieläpä täsmällinen sijainti, jolloin paikka on nimetty läheisen paikan mukaan. Haukijärvestä virtaa Haukijärvenoja ja järven lähellä on Haukijärvensuo. Järven rannalla oleva tila on voinut saada nimen Haukijärvi ja sen lähistöllä oleva pienempi järvi nimen Vähä Haukijärvi. Tällainen nimeäminen on hyvin taloudellista, koska tunnetun paikan nimeen pohjautuvat nimet on helppo tunnistaa ja niitä on myös helppo aina tarpeen tullen muodostaa. (Kiviniemi 1990, 124-126.)

Olemassa oleva nimistö voi vaikuttaa nimeämiseen myös niin, että nimi on voinut syntyä olemassa olevien nimien vastakohta- tai variointinimiksi. Mustalammen lähellä oleva lampi saa nimen Valkealampi, vaikka se ei erityisen valkeavetinen olekaan, kun se on kuitenkin "valkeampi" kuin tummavetinen Mustalampi. Kanakallio puolestaan saattaa saada selityksensä siitä, että sen lähellä on Kukkokallio. Nimeä voidaan varioida paitsi semanttisesti myös äänteellisesti, jolloin esimerkiksi Torisevan lähellä olevaa koskea aletaan kutsua Töriseväksi. (Ainiala ym. 2008: 95, 105-106; Kiviniemi 1971a.)

Aina ei välttämättä voi yksiselitteisesti sanoa, mikä paikka on nimetty ensin ja mikä myöhemmin toisen nimen mallin mukaan. Tällaista mallin mukaista eli analogista nimenantoa on systemaattisimmin tutkinut Eero Kiviniemi, joka väitöskirjassaan tarkasteli partisiipin sisältäviä nimiä. Useimmat tällaiset nimet perustuvat veden tai vetisen maaperän ääneen tai liikkeeseen. Lähes puolet ensimmäisen partisiipin sisältävistä paikannimistä (esim. Koliseva, Törisevä, Kohiseva) on syntynyt jo olemassa olleiden, samantyyppisten ja samakantaisten nimien mukaan. Vaikka usean nimen taustalla on muiden nimien antama malli, ovat analogisetkin nimet yleensä paikkaa kuvaavia. Ilman nimeämisperustetta niitä ei siis ole annettu. (Kiviniemi 1971b.)

Tällaisen yhden rakennetyypin kohdalla mallin osuutta nimenannossa on todennäköisesti helpompi selvittää kuin esimerkiksi "perusnimien", kaksiosaisten yhdysnimien kohdalla. Kun Valkealammen vieressä on Mustalampi, onko kyse mallin mukaisesta nimeämisestä vai vain siitä, että tällaiset nimet ylipäänsä ovat lammilla tyypillisiä ja että nimet myös sopivat kuvaamaan kohdettaan? Tällaista nimeämistä ei tutkimuksessa ole kutsuttu mallin mukaiseksi ja analogiseksi nimeämiseksi, vaan on todettu, että nimet noudattavat nimenantaja(yhteisö)n nimikielioppia (ks. esim. Kiviniemi 1975, 11-13.) Nimimalli voidaan siis yhtäältä hahmottaa hyvin laajaksi käsitteeksi, jolla tarkoitetaan sitä, miten nimiä kielessä yleensä muodostetaan, millaisten rakenteellisten ja semanttisten sääntöjen puitteissa. Toisaalta mallilla voidaan 


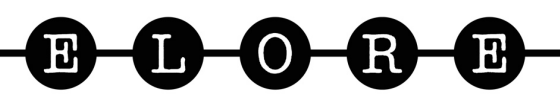

tarkoittaa suppeampaa käsitettä, jossa nimiä muodostetaan tietyn rakennetyypin mukaan ja tietyin semanttisin ehdoin.

Jo edellä lienee käynyt ilmi, että perinnäiset paikannimet ovat syntyneet nimenantajayhteisölle tutuista kielen aineksista. Paikannimi on aina syntyessään ollut paikkaa kuvaava ja luonnehtiva. Nimiin sisältyy sellaisia kielen sanoja ja johtimia, jotka muutoinkin ovat olleet kieliyhteisön käytössä nimenannon aikana. Rakenteeltaan suomalaiset paikannimet ovat tyypillisesti kaksiosaisia yhdysnimiä, joissa nimen jälkiosa ilmaisee paikan lajia ja alku- eli määriteosa paikan erityispiirrettä (esim. Musta/lampi). Erilaiset yksiosaiset nimet (esim. Valkeinen, Mustio) ovat toiseksi tavallisin rakennetyyppi. Jotkin yksiosaiset nimet ovat voineet muuttua kaksiosaisista yksiosaisiksi (Valkeajärvi > Valkeinen, Mustajoki > Mustio). (Ainiala ym. 2008, 110-112; Kiviniemi 1975.) Nimiä tulkitessa ei siis pidä lähteä siitä, että nimiin voisi olla kätkeytyneenä sanoja tai nimiä, joita yhteisö ei muutoin olisi tuntenut ja käyttänyt. Kun jotkin nimet ovat meille nykykielen puhujina hämäriä ja läpinäkymättömiä (esim. Imatra, Päijänne), se ei tarkoita sitä, että nimet olisivat olleet sitä syntyaikanaan. Se, ettemme me enää ymmärrä näitä nimiä emmekä siis osaa tulkita niiden alkuperäistä merkityssisältöä, johtuu siitä, että nimeen sisältyvät sanat ovat voineet kadota kielestämme, nimi on voinut muuttua vuosisatojen aikana tunnistamattomaksi tai nimi voi olla syntynyt meille tuntemattomassa (muinais)kielessä. (Ainiala ym. 2008, 114; Kiviniemi 1975, 11-13.)

Omaleimainen yksiosaisten nimien ryhmä ovat vertailevat siirrynnäiset, joita voidaan kutsua myös metaforisiksi nimiksi. Nimettävä paikka rinnastuu tällöin johonkin nimenantajan tuntemaan tai pikemmin kuvittelemaan jo nimettyyn paikkaan ja saa esimerkiksi nimen Amerikka, Siperia tai Kaanaa. Esimerkiksi etäällä talosta oleva, laaja-alainen ja ehkä hallanarkakin pelto voi saada nimen Siperia. Nimityyppi on kansainvälinen, ja tunnettuja ovat muuttajien antamat nimet, jolloin muuttajat ovat nimenneet uuden asuinalueensa entisen kotiseudun mukaan, ikään kuin sen muistoksi. Nimen alkuun on tällöin voitu liittää pientä tai uutta merkitsevä määrite (New York, Klein Amerika). (Ainiala ym. 2008, 104; Rentenaar 1996.) Tällaisten nimien myötä nimimaisema saa uuden merkitysten verkoston. Todennäköisesti tällä tavoin nimetyt paikat voivat myös muokata ja vahvistaa niitä (joskus stereotyyppisiäkin) käsityksiä, joita yhteisön jäsenillä nimien esikuvista on.

Koska paikannimet ovat syntyneet kieliyhteisölle tutuista sanoista ja muista kielenaineksista sekä olleet lisäksi paikkaa kuvaavia, voisi otaksua, että paikannimien avulla saa piirretyksi tarkan kuvan alueen luonteesta ja ominaispiirteistä. Voisi siis kuvitella, että nimimaisemasta piirtyy esiin tarkkapiirteinen ja "tosi" alueen kuvaus. Näin ei kuitenkaan oikeastaan ole. Syynä tähän on se, että yksilöivän tehtävän täyttääkseen nimen ei yleensä "kannata" olla paikkaa tyypillisimmällä tavalla kuvaava. Koska nimen tärkein tehtävä on yksilöidä kohteensa eli erottaa se muista, ennen kaikkea samanlajisista, paikoista, harvinainen erottaa paremmin kuin tyypillinen. Tästä seuraa myös se, että esimerkiksi luonnossa yleisimmät kasvit ja eläimet eivät ole vastaavasti edustettuina paikannimistössä. Esimerkiksi Haapa on nimistössä yleinen määriteosa, vaikka puuna haapa ja varsinkin haapavaltaiset metsät ovat suhteellisen harvinaisia. (Ainiala ym. 2008, 93-94; Kiviniemi 1990: 131-132.)

Nimistö muuttuu jatkuvasti. Koska nimet ovat kytköksissä paikan yksilöintitarpeeseen, jäävät sellaiset nimet pois käytöstä, joiden kohdetta ei enää ole tarvetta yksilöidä. Itse paikka on voinut hävitä tai muuttua voimakkaasti. Maanviljelyksen tehostuessa on esimerkiksi moni vähäisempi viljelysalue jäänyt vaille nimeämistarvetta, kun yhteen laajempaan 


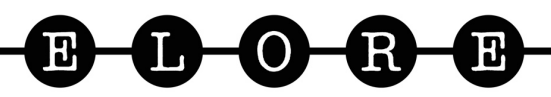

peltoalueeseen on voinut viitata yhdellä nimellä. Vielä 1960-luvulla maaseudun kylissä käytössä olleista nimistä oli 1990-luvulle tultaessa kadonnut keskimäärin noin puolet ja vähimmilläänkin noin kolmannes (Ainiala 2000). Elintapojen ja elinympäristön muutos on ollut pääsyynä nimien katoamiseen. Toisaalta uusia nimiä syntyy jatkuvasti, kun maisema muuttuu tai kun syntyy uusia tarpeita erottaa kohteita.

Nimi ei aina säily yhteisön käytössä, vaikka yhteisöllä olisikin katkeamaton tarve yksilöidä nimen kohde. Vanha nimi voi vaihtua uuteen. Paikalla on voinut tapahtua jotakin niin huomattavaa, että tämä tapahtuma on leimannut paikan ja entinen nimi on jäänyt syrjään. Esimerkiksi monet Surma-alkuiset nimet, jotka kertovat paikalla tapahtuneesta surmatyöstä tai muusta ihmisen tai eläimen kuolemasta, ovat usein jättäneet syrjään paikan aiemman nimen. Joskus tällaiset nimet tai esimerkiksi merkityssisällöltään läpinäkymättömät nimet voivat synnyttää erilaisia nimenselitystarinoita ja kansanetymologioita (Ainiala ym. 2008, 35). Tämä on luonnollista: koska nimeen lähtökohtaisesti aina sisältyy merkityssisältö, ihmiset pyrkivät "selittämään" oudoilta tai muuten erityisiltä tuntuvia nimiä ja kytkemään niihin erilaisia tarinoita. Ihminen ei siis tyydy siihen, että kohteella vain olisi jokin nimi, jolla sen voi yksilöidä, vaan ihminen haluaa antaa nimelle ja sen kohteelle myös jonkin merkityssisällön. (Nimiin kytketyistä tarinoista ja kansanetymologioista ks. tarkemmin Sejer Danielsen 2017.)

Tähän mennessä olen tarkastellut perinnäisten paikannimien rakennetta ja merkityksiä sekä niiden muodostamia kerrostumia osana ennen kaikkea maaseudun maisemaa. Seuraavaksi otan esiin kaupunkiympäristön nimistön ja tuon esiin sen eroja ja yhtäläisyyksiä perinnäisiin nimiin verrattuna.

\section{Kaupunkiympäristön paikannimet}

Kaupunkiympäristössä ja muualla kaavoitetuilla alueilla nimiä syntyy ensisijaisesti virallista tietä. Kadut, tiet, puistot ja muut kaavakohteet saavat nimensä viranomaistyönä ja poliittisin päätöksin. Viranomaiset ja poliitikot päättävät myös siitä, mitkä paikat asemakaavaan merkitään eli mitkä paikat ylipäänsä nimetään. Maassamme on satojatuhansia tällaisia suunniteltuja eli virallisia nimiä. Niitä myös syntyy koko ajan lisää, asemakaavoitetuille alueille kaavanimiä ja haja-asutusalueille tiennimiä. (Ainiala ym. 2008, 131-132.)

Kun perinnäiset paikannimet ovat alun perin syntyneet pienen yhteisön tarpeisiin ja suppeasta näkökulmasta, suunnitellut nimet luodaan alusta pitäen laajan yhteisön käyttöön. Kaupunkiympäristössä nimenantoa säätelee vielä sekin, että saman kaupungin alueella - tai mielellään edes yhtenäisellä kaupunkiseudulla, kuten pääkaupunkiseudulla - ei tulisi olla kahta samannimistä paikkaa. Kun esimerkiksi Helsingissä tarvitaan nimi uudelle kadulle, ei nimeksi voida antaa mitään niistä liki 8000 nimestä (Nimistönsuunnittelu), joita kaupungissa jo on. Lisäksi tulisi välttää Espoon ja Vantaan alueilla käytössä olevia nimiä. Kaksikielisillä alueilla myös nimet annetaan kahdella kielellä. Nimenanto konteksteineen on siis hyvin erilaista kuin perinnäisen nimistön kohdalla: kun agraarimaisemassa on riittänyt, että saman tilan alueella ei ole toista Riihipeltoa eikä saman kylän alueella toista Mustalampea (ainakaan tarpeettoman lähellä), tulee suunniteltua nimistöä annettaessa ottaa huomioon merkittävästi laajempi käyttäjäyhteisö ja ympäristö.

Kuten edellä jo kävi ilmi, perinnäisetkin paikannimet voivat näkyä myös osana urbaania kaavanimistöä. Nimistönsuunnittelun suositusten mukaisesti kaavanimistön ensisijaisena 
rakennusaineena käytetään alueen vanhaa perinnäistä paikannimistöä (Ainiala ym. 2008, 132). Sen lisäksi, että kaupunginosien ja osa-alueiden nimet ovat tyypillisesti alueen vanhojen kylien nimiä, perinnäisiä paikannimiä sisältyy lukuisiin kadunnimiin. Voidaan ajatella, että alueella kohtaavat silloin vanhan paikannimen esiin tuoma ja kaavanimen aikainen modernimpi kerros. Kaavanimeen sisältyvän perinnäisen paikannimen kohdetta ei välttämättä enää ole edes olemassa tai ainakin kohde on hyvin paljon muuttunut, mutta kaavanimi tuo kohteen nimineen kuitenkin osaksi nykyistä ympäristöä. Esimerkiksi Helsingin Pasila on nykyisin valtakunnallisestikin tunnettu alue ja rautatieasema, mutta nimen taustalla olevaa Pasilana tunnettua maatilaa ei enää ole olemassa (SPNK 2007).

Perinnäisiä paikannimiä sisältävien nimien lisäksi kaavanimistä voidaan erottaa kolme muuta pääryhmää: paikkaa kuvaavat nimet, muistonimet ja aihepiirinimet. Paikkaa kuvaavat nimet kertovat jotakin paikan luonteesta, esimerkiksi sen sijainnista (Rantakatu) tai siitä, mikä merkittävä rakennus kadun varrella on (Asemakatu, Kirkkokatu) tai mihin katu johtaa (Hämeentie). (Ainiala ym. 2008, 133.)

Muistonimet ovat vahva ja kiisteltykin osa suunniteltua nimistöä ja kaupunkimaisemaa. Muistonimet ovat nimiä, jotka on annettu jonkun henkilön, jonkin tapahtuman tai muun seikan muistoksi, ja pääosa niistä sisältää paikallisten tai valtakunnallisestikin tunnettujen henkilöiden nimiä. Se, keitä ja millaisia henkilöitä muistonimissä halutaan nostaa esiin ja kunnioittaa, on vahvasti ideologinen kysymys. Mikä ja ketkä katsotaan kaupungin tai valtakunnankin kannalta arvostetuiksi ja mikä ja ketkä puolestaan piilotetaan? Kadunnimiin päässeiden henkilöiden voi katsoa olevan osa hyväksyttyä historiankirjoitusta. Tunnettua on, että poliittisten vallanvaihtojen seurauksena nimistöäkin usein vaihdetaan. Itä-Euroopan maista on monia esimerkkejä siitä, kuinka sama katu on voinut vaihtaa nimeään useastikin. Kuitenkin myös Suomesta tunnetaan vastaavia tapauksia. Helsingissä vaihdettiin 1920-luvulla, maan itsenäistyttyä, muun muassa Vladimirinkatu Kalevankaduksi ja Nikolainkatu Snellmaninkaduksi. (Ainiala ym. 2008, 133-135; Ainiala 2012, 94.)

Keskusteluja olemassa olevien muistonimien vaihtamisesta syntyy melko säännöllisesti ja ehdotuksia uusien antamisesta tehdään. Tuoreimpia Helsingissä esiin nousseita keskusteluja on toive Lenininpuisto-nimen vaihtamisesta, joskin ensimmäiset aloitteet nimen muuttamisesta on tehty jo 1990-luvun alussa Neuvostoliiton hajottua. Nimi oli alun perin otettu käyttöön vuonna 1970 vasemmistoryhmän ehdotuksesta, kun Leninin syntymästä tuli kuluneeksi sata vuotta. Puisto oli tuolloin vasta perustettu, eikä sillä ollut entuudestaan nimeä. Motiivina nimen vaihtamiselle on esitetty sitä, että Leninin kaltainen hallitsija ei ansaitsisi nimeään osaksi virallista nimistöä. (Harling-Kranck 1999, 52; Lenininpuisto.) Nimeä ei kuitenkaan - ainakaan tätä kirjoitettaessa - olla vaihtamassa, sillä kaavanimistössä pysyvyyttä pidetään keskeisenä kriteerinä. Jos nimen vaihtamista todella harkittaisiin, tulisi pohtia monipuolisesti ja avoimesti sitä, milloin ja millaisin ehdoin muistonimi voidaan vaihtaa. Nähdäkseni olisi syytä välttää sellaisia linjauksia, jotka mahdollistaisivat muistonimen vaihtamisen uusien historiaa koskevien näkemysten tai muuttuvien ideologisten suuntaisten mukaisiksi.

Kaupunkien kaavanimistöstä suurin osa on aihepiiri- eli teemanimiä, jotka ovat jonkin aihepiirin mukaan muodostettuja nimiä. Esikaupunkialueilla aihepiirinimiä voi olla jopa 90 prosenttia kaavanimistä. Suosituksena on, että aihepiiri kytkeytyisi jollakin tavoin alueen paikallishistoriaan, elinkeinoihin tai muuhun alueen ominaisuuteen. Joskus kytkökset ovat 
voineet jäädä melko ohuiksi ja aina niitä ei ehkä edes ole. Esimerkiksi Kalevalan ja Seitsemän veljeksen mukaan on nimetty katuja ja teitä useissa Suomen kunnissa, vaikka seuduilla ei olisi konkreettista kytköstä näihin. Kun alueen nimistöstä suuri osa on johonkin teemaan liittyviä, saa se väistämättä leiman - tai ainakin mausteen - esimerkiksi kalastusaiheisena (Helsingin Vuosaaren Airoparintie, Keulatie, Peräsintie jne.) tai soitin- ja musiikkiaiheisena (Kannelmäen Pajupillintie, Tanotorventie, Viulutie jne.). (Ainiala ym. 2008, 135-137; Närhi 1999.)

Muistonimien lailla aihepiirinimet voivat herättää voimakkaitakin tunteita. Jos nimistä välittyy sellaisia paikkaan ja ympäristöön kytkeytyviä merkityksiä ja mielikuvia, jotka asukkaiden kannalta tuntuvat vierailta, voidaan nimiin suhtautua kielteisesti. Tämä tuli esiin Helsingin Vuosaaressa, sen Aurinkolahden osa-alueella, asuvien haastattelussa. Haastattelu on tehty vuonna 2006 osana Nimimaiseman muutos Helsingin sosiolingvistisesti moninaistuvissa kaupunginosissa -hanketta. (Hankkeesta tarkemmin ks. esim. Ainiala \& Lappalainen 2010.) Haastateltavat esimerkiksi kommentoivat, että he kutsuvat asuinaluettaan Vuosaareksi ja välttävät osa-alueen nimeä Aurinkolahti. Sitä ja monia muitakin alueen nimiä kuvaillaan "hirveen tekastun oloisiksi" ja "ei-todellisiksi".

Aurinkolahti on Vuosaaren osa-alueelle 1990-luvun puolivälissä annettu uusi nimi. Tämän nimistä luonnonpaikkaa ei alueella entuudestaan ollut, vaan merenlahti tunnettiin nimellä Mustalahti. Tätä nimeä ei kuitenkaan haluttu antaa alueelle, jota markkinoitiin houkuttelevana merenrantakaupunginosana. Alueelle luotiin imago, jonka rakennusaineeksi otettiin myös esimerkiksi aurinkoa ja merellisyyttä esiin tuova kaavanimistö, jossa Aurinkolahti alueen nimenä oli vahvin symboli. (Vuolteenaho ym. 2007, 21-23.) Haastateltavat ovat tietoisia nimen taustasta ja tuovat esiin sen, että he eivät arvosta tätä nimeä - eivätkä sen myötä todennäköisesti alueelle rakennettua imagoa ja brändiä. Nimen käytön karttaminen on vahva keino osoittaa, että ei halua jakaa alueeseen nimistön- ja kaupunkisuunnittelun keinoin kytkettyjä merkityksiä.

Samassa haastattelussa nousee osittain esiin sekin, että keskustelijat arvostavat "konkreettisia" ja "todellisia" nimiä. Tällaisiksi nimiksi nousevat nimet, jotka pohjautuvat alueen perinnäisiin nimiin ja lisäksi yksi muistonimi, Gustav Pauligin katu, johon sisältyy alueella vaikuttaneen henkilön nimi. Perinnäisiä paikannimiä käsiteltäessä kävi ilmi, että ne ovat aina syntyhetkellään olleet paikkaa luonnehtivia. Lisäksi tuotiin esiin se, että ihmisillä on luontainen taipumus antaa epäselville tai hämärille nimille merkityssisältö tai jollakin tavoin selittää nimeä. Aihepiirinimet eivät anna nimen taustasta ja kohteesta muuta tietoa kuin sen, että nimi kuuluu johonkin temaattiseen ryhmään. Monesti asukkailla voi kuitenkin olla tarve selittää nimeä, ja silloin selitykset voivat pohjautua siihen, millaisia nimeämisperusteita nimiin ylipäänsä tiedetään sisältyvän. Esimerkiksi Vuosaaressa haastateltu henkilö pohtii, mistä tulee nimi Adalmiinankatu, jolloin toinen haastattelun osallistuja otaksuu, että "tääl on varmaan ollu semmonen joku Adalmiina tärkee henkilö" (Ainiala 2016, 115). Todellisuudessa nimi kuuluu Topeliuksen satujen mukaan annettuihin aihepiirinimiin (Helsingin karttapalvelu). Kaavanimet siis synnyttävät erilaisia merkityksiä ja tarinoita, paljolti samoin tavoin kuin maaseudun maiseman moniselitteiset tai hämärtyneet paikannimet.

Kaupunkilaiset nimeävät lisäksi heille tärkeitä paikkoja virallisesta nimestä riippumatta tai muokaten virallisia nimiä. Joskus syy tällaisen epävirallisen nimen antamiseen voi olla käytännöllinen: epävirallinen nimi on lyhyempi ja helppokäyttöisempi. Epävirallinen nimi voi myös olla niin vakiintunut, että paikka yksinkertaisesti opitaan tuntemaan näin. Näitä nimiä 


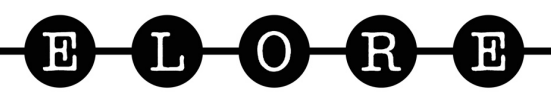

voidaan hyödyntää esimerkiksi julkisissa tiedotteissa ja mediateksteissä sekä osana kaupallista nimi- ja kielimaisemaa. (Ainiala ym. 2008, 137-138, 151-152.)

Epävirallinen nimi voi myös olla keino osoittaa identiteettiä, identifioitumista jonkin ryhmän jäseneksi tai tietynlaiseksi kaupunkilaiseksi. Varsinkin monet slanginimet täyttävät tätä tehtävää. Tunnetuimpia esimerkkejä ovat Helsingistä käytetyt slanginimet Hesa ja Stadi, joiden käyttöön liittyy laajalti tiedostettuja normeja siitä, kuka saa tai kenen kuuluu käyttää tai olla käyttämättä näitä nimiä. Molemmat nimet ovat syntyneet syntyperäisten helsinkiläisten kielenkäytössä ja kuuluvat varhaisimpaan slangikerrostumaan, mutta toisen maailmansodan jälkeen Hesa on leimautunut muualta muuttaneiden ja maalaisten käyttämäksi. (Ks. tarkemmin Ainiala \& Lappalainen 2010.) Epävirallisessa nimistössä voidaan osoittaa myös ironiaa virallista nimeä tai nimen kohdetta kohtaan tai nimestä kohteineen voidaan haluta erottautua (Ainiala ym. 2008, 141-142). Erilaiset Juoppo- ja Narkkaripuistot ja vertailevat siirrynnäiset, kuten Bronks ja Harlem, ovat esimerkkejä tällaisista nimistä. Epäviralliset nimet ovat silloin keino erottaa maisemasta "meidän ja muiden" paikkoja.

\section{Lopuksi}

Nimimaisemaan sisältyy yleensä sekä perinnäisiä että suunniteltuja nimiä. Nekin koostuvat useista eri kerrostumista: eri-ikäisistä, erikielisistä ja eri tavoin syntyneistä nimistä. Esittämäni nimistöntutkimuksen lähtökohtien ja nimimaisemien kerroksellisuuden kuvaus toivottavasti auttaa ja innostaa myös perinteentutkijaa hänen pohtiessaan nimien merkityksiä. Kokoan vielä pohdintani päätulokset yhteen.

Nimistö on paikkoja ja aluetta luonnollisella tavalla luonnehtiva "kuvaus", mutta myös monin tavoin valikoiva ja joskus vääristäväkin. Koska nimen ensisijainen tehtävä on yksilöidä kohteensa, nimeksi ei likikään aina valita paikkaa tyypillisimmin kuvaavaa. Kaupunkimaisemassa on lisäksi nimiä, varsinkin muisto- ja aihepiirinimiä, joiden ei voi sanoa luonnehtivan kohdettaan muutoin kuin olemalla osa jotakin määrättyä teemakokonaisuutta tai jotka kunnioittavat jotakuta henkilöä, joka ei välttämättä ankkuroidu alueelle.

Perinnäisten paikannimien avulla tutkija voi saada tietoja siitä, keitä alueella eri aikoina on liikkunut ja asunut sekä millä perusteilla he ovat paikkoja nimenneet. Suunniteltu nimistö puolestaan tuo esiin sen, mikä ja millainen nimistö on katsottu poliittisin päätöksin "auktorisoiduksi". Suunnitellun nimistön maisemassa elävä voi kuitenkin olla käyttämättä nimiä, joiden esittämiä merkityksiä hän ei koe omakseen, ja käyttää sen sijaan esimerkiksi epävirallista nimistöä.

Perinnäistä ja suunniteltua nimistöä voidaan monessa kohdassa verrata toisiinsa ja asettaa ne vastakkainkin, mutta molemmille on yhteistä se, että ne tuovat esiin käyttäjiensä kokemuksia paikoista. Paikannimien tulkinta ja tutkimus edellyttää kykyä hahmottaa nimistön rooli osana kielenkäyttöä, kulttuuria ja yhteiskuntaa. Nimistöntutkimus on osa kielentutkimusta, mutta se on myös tieteenala, jolle monitieteiset ja tieteidenväliset näkökulmat ja lähestymistavat ovat luonteenomaisia. Paikannimien tutkija ei koskaan tutki vain nimiä kielellisinä ilmauksina vaan aina myös nimien kohteita: paikkoja ja alueita. Siksikin tarvitaan laaja-alaisemmin yhteistyötä eri alojen tutkijoiden kesken. Yhteistyön ja monipuolisten tutkimusmenetelmien avulla saadaan näkyviin nimistön kuvaamia merkityksiä. 


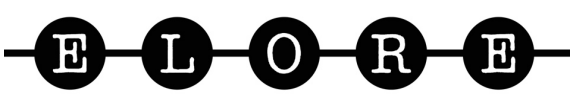

\section{Tutkimusaineistot}

Tutkimushankkeessa "Nimimaiseman muutos Helsingin sosiolingvistisesti moninaistuvissa kaupunginosissa" Vuosaaressa koottu haastatteluaineisto, jossa haastateltiin 38 asukasta (ryhmä- ja yksilöhaastatteluja) vuosina 2004-2008. Haastattelijoina hankkeen tutkijat Terhi Ainiala ja Jani Vuolteenaho sekä hankkeen tutkimusavustajia ja pro gradu-tutkielman tekijöitä (Tiina Karbin, Tiina Likki, Saara Tikkala ja Teemu Tegelman). Aineisto (äänitteet ja tekstilitteraatit) säilytetään CSC:n kielipankissa.

\section{Kirjallisuus}

Ainiala, Terhi 2000: Paikannimistön muuttuminen. - Virittäjä 104: 355-372.

Ainiala, Terhi 2001: Paikannimistön keruun tavoitteet ja tulokset. - Mallat, Kaija, Terhi Ainiala \& Eero Kiviniemi (toim.), Nimien maailmasta. Helsinki: Helsingin yliopiston suomen kielen laitos. 7-22.

Ainiala, Terhi 2012: Tähtitorninmäeltä Pitkällesillalle - paikannimiä kaupunkikuvassa. Meinander, Henrik (toim.), Unioninakseli - pääkaupungin läpileikkaus. Helsinki: Teos. 90-97.

Ainiala, Terhi 2016: Attitudes to street names in Helsinki. - Puzey, Guy \& Laura Kostanski (toim.), Names and naming. People, places, perceptions and power. Bristol: Multilingual Matters. 106-119.

Ainiala, Terhi \& Hanna Lappalainen 2010: Miten Helsingistä puhutaan? - Virittäjä 114: 71-107.

Ainiala, Terhi, Minna Saarelma \& Paula Sjöblom 2008: Nimistöntutkimuksen perusteet. Helsinki: SKS.

Bright, William 2003: What is a name? Reflections on onomastics. - Language and Linguistics 4.4: 669-681.

Harling-Kranck, Gunilla 1999: Helsingin ruotsinkieliset kadunnimet. - Helsingin kadunnimet

3. Helsinki: Helsingin kaupungin nimistötoimikunta. 46-55.

Helsingin kadunnimet. Toinen, korjattu painos. Helsinki: Helsingin kaupunki 1981.

Helsingin karttapalvelu [online] < http://kartta.hel.fi/ > [11.1.2018.]

Kepsu, Saulo 2005: Uuteen maahan. Helsingin ja Vantaan vanha asutus ja nimistö. Helsinki: SKS.

Kiviniemi, Eero 1971a: Vastakohta- ja variointinimistä. - Virittäjä 75: 123-134.

Kiviniemi, Eero 1971b: Suomen partisiippinimistöä. Ensimmäisen partisiipin sisältävät henkilön-ja paikannimet. Helsinki: SKS.

Kiviniemi, Eero 1975: Paikannimien rakennetyypeistä. Helsinki: SKS.

Kiviniemi, Eero 1987: Voidaanko nimeämisperusteet luokitella? - Kiviniemi, Eero \& Pitkänen, Ritva Liisa (toim.), Näkymiä nimistöön. Kieli 2. Helsinki: Helsingin yliopiston suomen kielen laitos. 7-34.

Kiviniemi, Eero 1990: Perustietoa paikannimistä. Helsinki: SKS.

Lenininpuisto [online] < https://yle.fi/uutiset/3-9751217 > [10.1.2018.]

Nimistönsuunnittelu [online] < https://www.hel.fi/helsinki/fi/asuminen-ja-ymparisto/ kaavoitus/kaavoituksen-tasot/nimistonsuunnittelu/ > [10.1.2018.] 
Närhi, Eeva Maria 1999: Ratamestareita, Pasuunoita, Orpaanportaita - Aihepiirien käyttö nimistönsuunnittelussa. - Helsingin kadunnimet 3. Helsinki: Helsingin kaupungin nimistötoimikunta. 22-33.

Pitkänen, Ritva Liisa 1996: Viljelijän kylä - kalastajan saaristo: ammatti nimitaidon taustana. - Pitkänen, Ritva Liisa, Helena Suni \& Satu Tanner (toim.), Kielen kannoilla. Kotimaisten kielten tutkimuskeskus 20 vuotta. Helsinki: Kotimaisten kielten tutkimuskeskus. 102-118.

Rentenaar, Rob 1996: Namen in Sprachaustauch. Toponymische Nachbenennung. - von Eichler, Ernst, Gerold Hilty, Heinrich Löffler, Hugo Steger \& Ladislav Zgusta (Hrsg.), Namenforschung. Ein internationales Handbuch zur Onomastik / Name Studies. An International Handbook of Onomastics / Les noms propres. Manuel international d'onomastique. 2. Teilband. Berlin: de Gruyter. 1013-1018.

Sejer Danielsen, Martin 2017: Da Lille Peder fik Per Lilles Eng i faddergave: Et studie af stednavneforklarendeelementeriden folkloristiskegenresagn [online] $<$ http://static-curis. ku.dk/portal/files/186419048/Ph.d. afhandling 2017 Danielsen.pdf $>$ [10.1.2018.]

SPNK = Suomalainen paikannimikirja 2007. Päätoimittaja: Sirkka Paikkala. Helsinki: Karttakeskus ja Kotimaisten kielten tutkimuskeskus.

Vuolteenaho, Jani,Terhi Ainiala \& Elina Wihuri 2007: Asuntosäästäjien Tapiolasta Helsingin East Endiksi: kaava- ja taloyhtiönimistö Vuosaaren kasvun vuosikymmeninä. Yhdyskuntasuunnittelu 45: 7-29.

Dosentti Terhi Ainiala on nimistöntutkija ja suomen kielen yliopistonlehtori Helsingin yliopistossa. 